\title{
COMBINED MECHANICAL BIO-HYDROMETALLURGICAL RECYCLING PROCESS OF PRINTED CIRCUIT BOARDS IN BRAZIL
}

\author{
Luciana Harue Yamane ${ }^{\prime *}$ \\ Carina Ulsen ${ }^{2}$ \\ Denise Crocce Romando Espinosa ${ }^{3}$ \\ Jorge Alberto Soares Tenório ${ }^{3}$
}

\begin{abstract}
Precious metal content is much higher in electronic waste than in most worldwide mines, and therefore recycling is encouraged and mostly performed by hydrometallurgical and pyrometallurgical processes. This paper addresses a combined mechanical bio-hydrometallurgical recycling process for extracting gold, copper and iron from printed circuit boards as a less expensive technology feasible for the Brazilian context. Metal recovery was carried out by combining physical, chemical and biological processes. The combined process proved to be technically viable; the microbiological route using adapted bacteria Acidithiobacillus ferrooxidans-LR is also eco-friendly. Mechanical processes recovered $97 \%$ of the iron by magnetic separation, the bioleaching extracted $99 \%$ of the copper, and $86 \%$ of the gold was recovered during the last stage of cyanidation.
\end{abstract}

Keywords: Printed circuit boards; Combined recycling route; Bioleaching; Hydrometallurgy.

\section{INTRODUCTION}

Recycling of WEEE warrants the extraction of metals from printed circuit boards $(\mathrm{PCB})$ that have economic potential, due to the presence of metals such as copper, precious metals, and other metals that are considered critical [I]. Despite the well-known heterogeneity of PCB, copper is commonly found in greater quantities and, on average, reaches $20 \%$ by mass of typical personal computer's PCBs [2].

Metals and/or metal compounds are recovered from PCBs at varying degrees of efficiency, depending on their value, and in the case of copper, which has lower market value when compared to precious metals, the extraction is justified by the concentration found, in addition to minimizing the extraction of non-renewable natural resources from primary sources $[1,3]$. Despite containing more than $90 \%$ of recyclable compounds, Brazil does not have recycling plants and a structured management system even after the approval of the Brazil's Solid Waste National Policy that establishes the obligation of e-waste reverse logistic [4]. A fraction of the e-waste goes to informal markets; another is added to the rest of the domestic waste and landfilled despite environmental contamination concerns; and a minor portion is collected, crushed and exported to other countries for metal recovery [5]. The estimate is that just $2 \%$ of eletronic waste is recycled in the whole country [6].
According to the Technical Feasibility Study performed by the Brazilian Agency for Industrial Development, the challenge of recycling electronic waste lies in the cost of reverse logistics in a continental country with particular logistical complexities [7]. Therefore, a recycling process must be less costly and as profitable as possible to compensate transportation distances. The lack of investment in recycling plants makes the metal recovery of gold impossible, which could otherwise finance the process, and the e-waste collection companies have only exportation as a possibility after removing PCBs.

The lack of a common solution for handling electronic waste and the environmental concerns of illegal recycling practices motivate further studies to expand recycling practices and legal disposal [8-10]

In general, recycling printed circuit boards involves hydrometallurgical and pyrometallurgical processes. Despite the gains obtained, several environmental and economic considerations must be considered. In a pyrometallurgical process, a massive investiment is necessary, and there are concerns regarding the energy required by the ovens and the generation of potentially polluting gases from brominated compounds used as flame retardants [ $1 \mathrm{I}-\mathrm{I} 3]$. In a hydrometallurgical process, the amount of inputs such

'Departamento de Engenharia Ambiental, Universidade Federal do Espírito Santo, Espírito Santo, Brasil.

${ }^{2}$ Departamento de Engenharia de Minas e de Petróleo, Universidade de São Paulo, São Paulo, Brasil.

${ }^{3}$ Departamento de Engenharia Química, Universidade de São Paulo, São Paulo, Brasil.

*Corresponding author: lucianayamane@gmail.com

2176-I523 C 2020. Yamane et al. Published by ABM. This is an Open Access article distributed under the terms of the Creative Commons Attribution License, which permits unrestricted use, distribution, and reproduction in any medium, provided the original work is properly cited. 


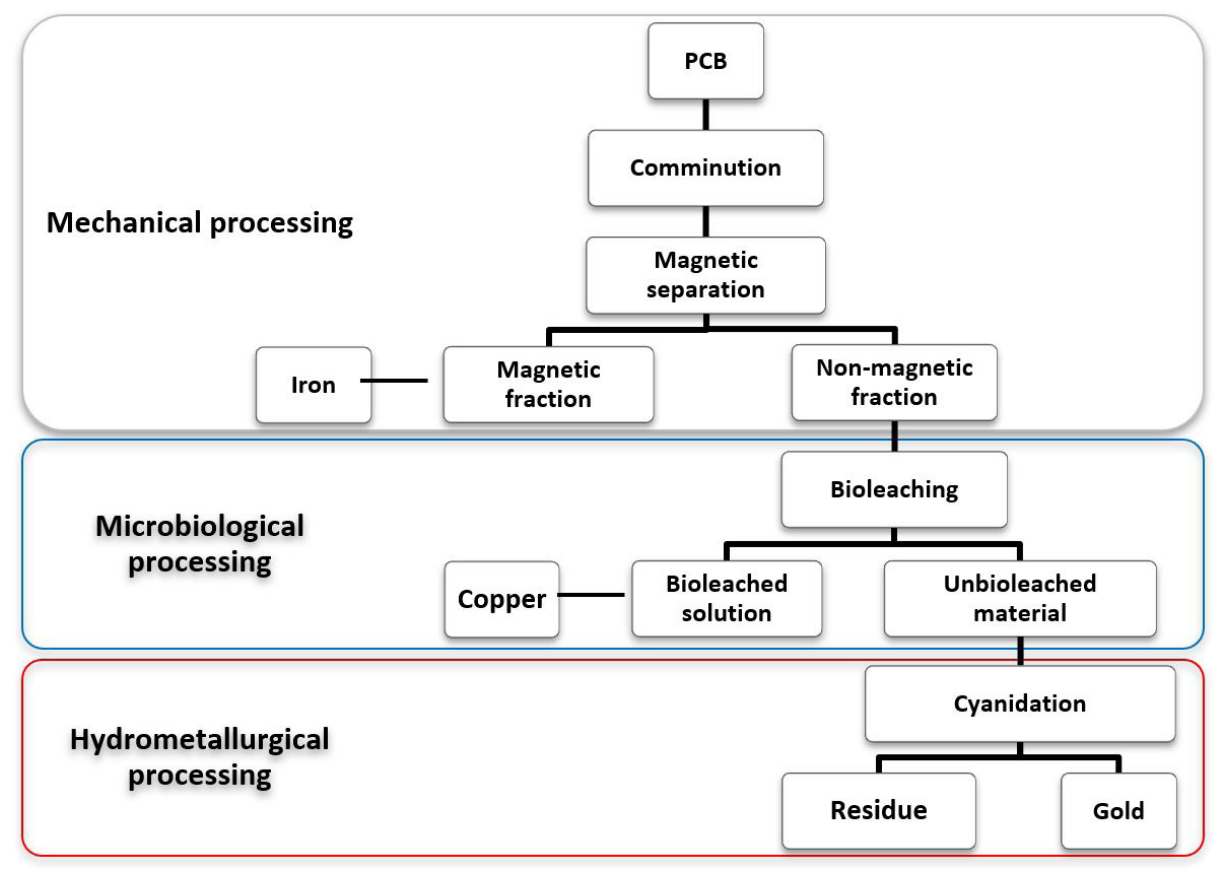

Figure I. Mechanical bio-hydrometallurgical route of printed circuit board recycling.

as acids and the need for installations and qualified operators make the process costly [14-16].

The undeniable relevance of a final destination for electronic waste encourages research tor develop cheaper and environmental friendly recycling processes to recover raw materials from the ever-increasing production of electronic equipment [I], to extend landfill life [I5] and to contribute to the circular economy, especially in developing countries such as Brazil.

The reduction of energy and acid requirements could be achieved by optimizing the integration of mechanical, chemical and biological separation processes [13].

Bio-hydrometallurgical processes involve biosorption [17], biofilms [18] and bioleaching with different types of microorganisms. Among the different microorganisms (fungus and bacteria) used in bioleaching processes, Acidithiobacillus ferrooxidans is the widest studied bacteria of all extremely acidophilic prokaryotes [19]. PCB bioleaching using Acidithiobacillus ferrooxidans is reported in several studies [20-22].

This paper addresses a combined mechanical bio-hydrometallurgical process for obtaining gold, copper and iron from printed circuit board scrap as a feasible technology for the Brazilian legal and economic context.

\section{MATERIAL AND METHODS}

\section{I Material}

An amount of $50 \mathrm{~kg}$ of $\mathrm{PCB}$ were removed from obsolete computers for the current study. Batteries and capacitors were extracted from PCBs.
The bacterium used in bioleaching experiments was Acidithiobacillus ferrooxidans', strain LR. T\&K medium used for growing the bacterial inoculum was composed of two solutions ( $\mathrm{A}$ and $\mathrm{B}$ ). Solution $\mathrm{A}$ was composed of (in $\mathrm{gL}^{-1}$ ) $\left(\mathrm{NH}_{4}\right)_{2} \mathrm{SO}_{4}(0.625), \mathrm{MgSO}_{4} .7 \mathrm{H}_{2} \mathrm{O}(0.625)$, and $\mathrm{K}_{2} \mathrm{HPO}_{4}(0.625)$, and solution $\mathrm{B}$ was composed of (in $\mathrm{gL}^{-1}$ ) $\mathrm{FeSO}_{4} .7 \mathrm{H}_{2} \mathrm{O}$ (166.5) [23]. The pH of both solutions was decreased to I. 8 by adding $\mathrm{H}_{2} \mathrm{SO}_{4} 5 \mathrm{M}$; in addition, solution $A$ was sterilized by autoclaving during $30 \mathrm{~min}$ at $120^{\circ} \mathrm{C}$ and I atm, while solution $B$ was filter-sterilized at $0.45 \mu \mathrm{m}$. Therefore, both solutions were mixed at proportion of 4-A:I-B.

Acidithiobacillus ferrooxidans was selected for the bioleaching processes due to its tolerance to the presence of heavy metals [15,24]. This bacterium gets energy from the oxidation of $\mathrm{Fe}^{2+}$ and reduced sulfur compounds and produces important oxidant agents, such as ferric ion and sulfuric acid [24].

\subsection{Methods}

Recycling of PCBs was performed using mechanical processing, bioleaching and hydrometallurgical extraction (cyanide leaching) as shown in the Figure I.

\subsection{Mechanical processing}

Mechanical processing was carried out on the collected PCBs by comminution and magnetic separation aiming to concentrate metals (especially copper and gold) and extract iron, which is prejudicial to copper bioleaching. Printed

' Courtesy of Chemistry Institute, State University of São Paulo - UNESP, Araraquara, Brazil. 
circuit boards were ground in a hammer mill to a size below $2 \mathrm{~mm}$ and therefore submitted to magnetic separation in a cross-belt separator to obtain magnetic and non-magnetic products. The composition of such products was previously reported in the literature [25]. The non-magnetic product was forwarded to the bioleaching experiments and bacterial adaptation; chemical composition is shown in Table I.

As can be seen in Table I, only $0.4 \%$ of iron remained of magnetic products from an initial concentration of $5.03 \%$, showing the magnetic separation efficiency.

\subsubsection{Bioleaching experiments}

Bioleaching experiments were carried out to extract copper from the non-magnetic product of PCBs using pre-adapted culture of $A$. ferrooxidans-LR.

The bacterial adaptation process was conducted by means of sequential subcultures, and the bacteria was grown in the presence of printed circuit boards (non-magnetic product), initially in the concentration $2.5 \mathrm{gL}^{-1}$, acquiring resistance to the products of chemical and biological leaching. Successive growths were made, with a $0.5 \mathrm{gL}^{-1}$ increase in the concentration of printed circuit boards with each successive subculture, using an aliquot of $10 \mathrm{~mL}$ of the previous growth containing the adapted bacteria as inoculum, in this way gradually raising the bacterial tolerance to increased concentrations of printed circuit boards up to a level of $45 \mathrm{gL}^{-1}$. The bacterial adaptation process was carried out for 4 months.

The shaking experiment was carried out in sterilized Erlenmeyer flasks with $200 \mathrm{~mL}$ of culture medium at room temperature $\left(25-30^{\circ} \mathrm{C}\right)$ in a rotary shaker. PCB samples (non-magnetic fraction) were added to each flask under aseptic conditions. The bioleaching system was maintained acidic $(\mathrm{pH}$ I.8-2.0) with the addition of sulfuric acid (I M) when necessary. The following conditions were studied: slurry density, inoculum volume, rotation speed and initial ferrous iron concentration.

Different slurry densities $\left(\mathrm{gL}^{-1}\right)$ were evaluated: $15,22.5,30,45,60,75$. Inoculum volumes evaluated were $(\% \mathrm{v} / \mathrm{v}): 5,10,20,30,40,50,60$ at three different rotation speeds (rpm): 150, 160, 170. Three initial ferrous iron concentrations also were analyzed $\left(\mathrm{gL}^{-1}\right)$ : 6.75, 13.57, 16.97 . Abiotic controls were run in parallel. Samples $(15 \mathrm{~mL})$ were periodically withdrawn $\left(I, 2,3,4,5,6,7,10,13\right.$ and $I 5^{\text {th }}$ days $)$ for copper analyses from bioleached solution.

The aliquots from the leaching were spun during 20 minutes at $5000 \mathrm{rpm}$ rotation speed. Two drops of concentrated $\mathrm{HNO}_{3}$ were added, and the samples were preserved in amber flasks at $4{ }^{\circ} \mathrm{C}$ until chemical analysis.

\subsubsection{Cyanidation}

Insoluble material from bioleaching was leached by cyanide for gold extraction. Cyanidation was conducted in Erlenmeyer flasks $(250 \mathrm{~mL})$ containing $\mathrm{NaOH}$ solution $(\mathrm{pH}$ I I) with $30 \%$ of solid concentration at room temperature $\left(25-30^{\circ} \mathrm{C}\right)$.

Erlenmeyer flasks were constantly shaken ( $150 \mathrm{rpm}$ ) to disseminate cyanide and dissolved oxygen. After $\mathrm{pH}$ stabilization (10 $\mathrm{min}$ ) in alkaline condition above 10.5, sodium cyanide was added $\left(5 \mathrm{gL}^{-1}\right)$. Leaching was carried out for $\mathrm{I} 44 \mathrm{~h}$; the $\mathrm{pH}$ was monitored and adjusted to a value above 10.5 using $\mathrm{NaOH}$ I $\mathrm{M}$ when necessary to avoid formation of cyanide gas. The concentration of free cyanide was also monitored by titration and adjusted with $\mathrm{NaCN}_{(s)}$, when necessary, to keep the concentration above $200 \mathrm{ppm}$. Samples $(10 \mathrm{~mL})$ were periodically withdrawn $(\mathrm{I}, 4,8,12,18,36,48,72,102$ and I44h) for gold analyses from leached solution.

The need to replace the cyanide during experiments is due to the decomposition of the cyanide ion, which is thermodynamically unstable and has a natural tendency to degrade [26].

\subsubsection{Analytical methods}

The metal content was assessed by atomic absorption spectroscopy (AAS). The initial Cu concentration (CC) shown in Table I was used to calculate the copper extraction rate; the final concentration of $\mathrm{Cu}$ (leach CC) was analyzed in leached liquor samples collected from bioleaching experiments. The same principle was used to calculate the gold extraction.

\section{RESULTS AND DISCUSSION}

\section{I Bioleaching Experiments}

As shown in Figure 2, the increase in slurry density caused a decrease in copper extraction. The lower the slurry density, the greater the volume of leaching solution per mass of concentrate, which increases the metallic solubilization [27].

In addition, bacterial activity can be inhibited by higher concentrations, which vary from 0.45 to $4.45 \mathrm{gL}^{-1}$, and therefore the increase in the pulp density can significantly inhibit the activity of the microrganisms $[24,27,28]$. Guo [29] described a similar effect of slurry density on the bioleaching of melted $\mathrm{Pb} / \mathrm{Zn}$ waste.

The highest copper extraction (97.2\%) was achieved at a slurry density of $15 \mathrm{gL}^{-1}$ after 15 days (Figure 2).

Table I. Composition of non-magnetic product material from printed circuit boards

\begin{tabular}{cccccccccc}
\hline Metal & $\mathbf{C u}$ & $\mathbf{S n}$ & $\mathbf{P b}$ & $\mathbf{A l}$ & $\mathbf{Z n}$ & $\mathbf{F e}$ & $\mathbf{N i}$ & $\mathbf{A g}$ & $\mathbf{A u}$ \\
\hline Content $(\%)$ & 28.1 & 7.8 & 4.9 & 4.5 & 3.9 & 0.4 & 0.2 & 0.1 & 0.1 \\
\hline
\end{tabular}


More than $70 \%$ of the copper was bioleached at pulp densities of between 15 and $22.5 \mathrm{gL}^{-1}$ since the bacterial adaptation had increased the bacteria's tolerance to the ions generated in the oxidation of the metals contained in printed circuit boards. Previous studies focused on recovering copper from printed circuit boards in shaken flasks indicate similar results and copper extraction rates over than 70\% [30-32].

At the highest pulp density $\left(75 \mathrm{gL}^{-1}\right)$, the copper extraction was less than $20 \%$, the same level as that obtained with abiotic controls (Figure 2), showing that at this pulp density copper extraction was not influenced at all by bacterial activity, with only chemical leaching of the copper having occurred.

Few studies [30-34] note the toxicity of the printed circuit boards, and in spite of the fact that the bacterial adaptation increases the tolerance to metallic ions, probably due to the quantity of PCB added to the leaching environment, in the case of pulp densities of $30,45,60$ and $75 \mathrm{gL}^{-1}$, there may have been an increase in the lysis condition of the cells in addition to having a negative impact on the process of transfer of mass [32]. Even so, at pulp densities of between 15 and $60 \mathrm{gL}^{-1}$, the extraction of copper obtained from the bioleaching was greater than that achieved with the abiotic controls. llyas et al. [30] suggests that the non-metallic components of the printed circuit boards also have a toxic effect on the bioleaching process due to their alkalinity, noting the increase in the initial $\mathrm{pH}$ when the unwashed electronic scrap was added to the leaching environment. Vestola et al. [35] suggests that the inhibition is due to the presence of organic solvent residues present in the circuit boards.

The oxidized solution is used to inoculate bacteria that are in the exponential growth phase, as follows: the lag phase (adaptation phase), the exponential phase, the stationary phase and the death phase. In the exponential phase, the number of cells increases exponentially and causes an increase in the bacterial metabolic activity involving the oxidation of the ferrous ion turning it into ferric ion and the subsequent solubilization of the copper [36].

Figure 3 presents the results obtained in the extraction of copper with different volumes of oxidated culture solution as inoculum. As can be observed in Figure 3, with a $10 \%$ inoculum a $99.2 \%$ extraction level of copper was achieved, with this being the best result obtained. The main difference observed using a $10 \%$ inoculum solution was that the exponential phase of bacterial growth occurred by the $2^{\text {nd }}$ day, while with a $5 \%$ inoculum this phase occurred by

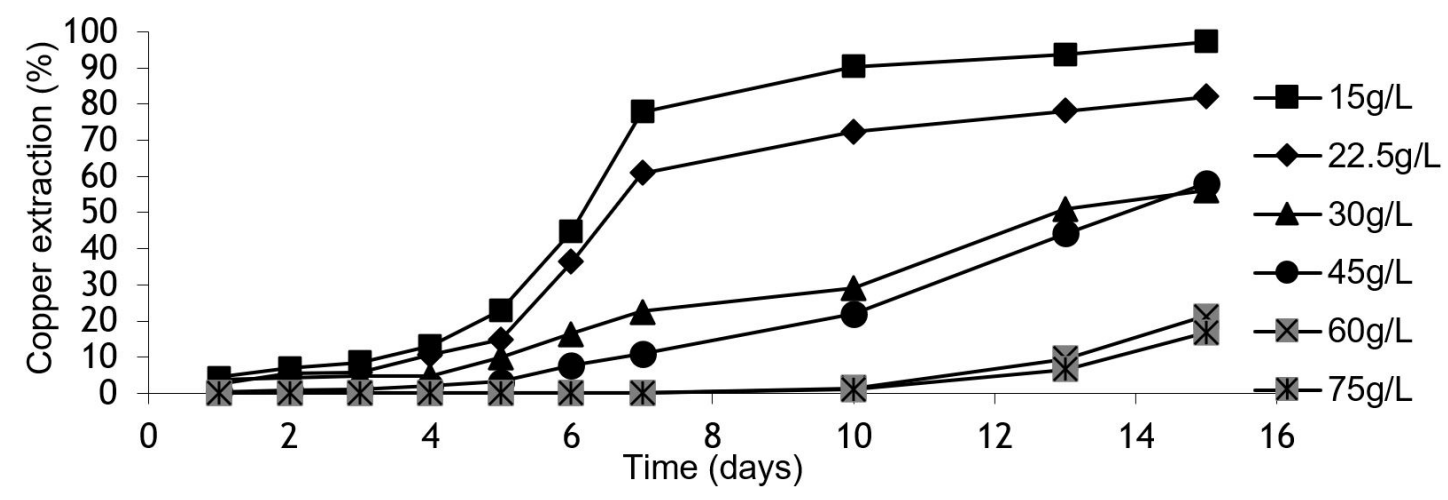

Figure 2. Copper extraction (\%) from I up to I5 days for different slurry densities.

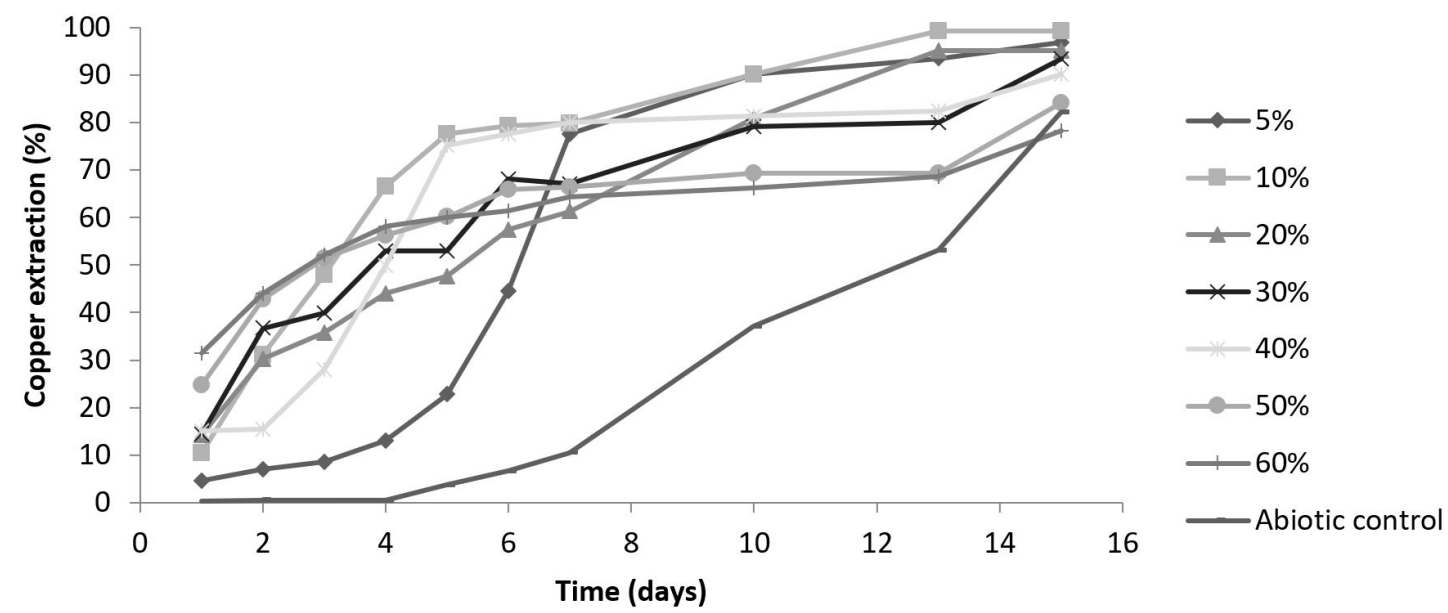

Figure 3. Copper extraction (\%) from I up to I5 days obtained using inoculum volume from 5 to $60 \%$ and abiotic control. 
the $6^{\text {th }}$ day. This occurred because using a $10 \%$ inoculum, a greater number of cells were introduced into the environment than with a $5 \%$ inoculum, and this increase in the number of cells meant that the available $\mathrm{Fe}^{+2}$ was oxidized more quickly, as observed in Figure 3, with the consequent extraction of $80 \%$ of the copper in 5 days. The increase in copper extraction from the $5^{\text {th }}$ day onward was probably due to the leaching of the copper (caused by the acidic culture), and it can therefore be inferred that the bacterial growth may have entered the stationary phase, in which the number of cells remains the same or in which there is almost no replication.

With the increase in the volume of the oxidized culture solution being inoculated to the environment, consequently, the amount of $\mathrm{Fe}^{+2}$ available is less (in the culture environment), and how the bacterial growth is closely linked to the biological oxidization of the ferrous ion in order to obtain energy, even with the innoculation of a greater number of cells, no significant increase in the level of copper extraction was observed, when volumes in excess of $30 \%$ of the oxidized culture solution were inoculated. In addition to this, the oxidization of $\mathrm{Fe}^{+2}$ can be inhibited in the presence of ferric ion concentrations $\left(10 \mathrm{gL}^{-1}\right)$ [37].

In oxidized culture solution, ferrous ion was completely oxidized turning it into the ferric íon prior to the inoculation to the environment. In other words, the greater the inoculated volume, the greater the initial concentration of $\mathrm{Fe}^{+3}$, which leads to a greater initial extraction of copper, as observed in the situations with between 50 and $60 \%$ of inoculum volume. From the $5^{\text {th }}$ day onward, the extraction remains constant up until the end of the experiment. The leaching caused by the ferric ion was not the only factor responsible for the obtained extraction level gerater than $60 \%$. The attained results demonstrated that the direct mechanism contributed to the copper extraction better than the indirect mechanism (oxidation by the ferric ion) did.

In studies of shaken flasks, the oxygen is introduced into the leaching environment by means of constant shaking.
The availability of oxygen is fundamental, given that the bacteria A. ferrooxidans is aerobic and consumes the $\mathrm{O}_{2}$ in the oxidization of the ferrous ion $[21,22]$. According to Lewis et al. [38], the temperature and the shaking speed have proven to be the factors that have the greatest impact on the kinetics of the copper's dissolution.

It was argued in the earlier experiments that the effect of the chemical leaching of the metals (abiotic controls), particularly of copper, was due to the introduction of oxygen brought about by the shaking. The study using different rotation speeds was carried out to verify the possibility of reducing the rotation speed, thus eliminating the effect of the chemical leaching without compromising the extraction of the copper by bioleaching. The results obtained in relation to the extraction of copper (\%) under different rotation speeds are presented in Figure 4.

As can be seen in Figure 4, the greatest extraction of copper (99\%) was achieved using a rotation velocity of $170 \mathrm{rpm}$. Bioleaching studies [30,32-34,39] report extraction rates of more than $70 \%$ with shaking speeds ranging from 150 to $250 \mathrm{rpm}$, but using rotation speeds of between 150 and $160 \mathrm{rpm}$, copper extraction dropped to less than $60 \%$, due to the reduction of the transfer of mass as the rotation speed diminished.

Due to the aerobic nature of $A$. ferrooxidans, the dissolved oxygen is a restricting factor for the bacterial growth, with growth not being observed for concentrations of less than $0.2 \mathrm{mgL}^{-1}$ [24]. Even though the oxygen dissolved in the environment was not measured, it can be observed that the reduction in the rotation speed, and therefore, in the introduction of oxygen into the environment, resulted in a decrease in copper extraction, with it being expected that slower speeds than those used may inhibit bacterial growth. Shaking the culture not only leads to the introduction of oxygen but also $\mathrm{CO}_{2}$, required as a source of carbon in the bacterial metabolic activity [15].

Studies of shaken flasks are usually used on a laboratory scale, but the determination of the rotation speed occurs

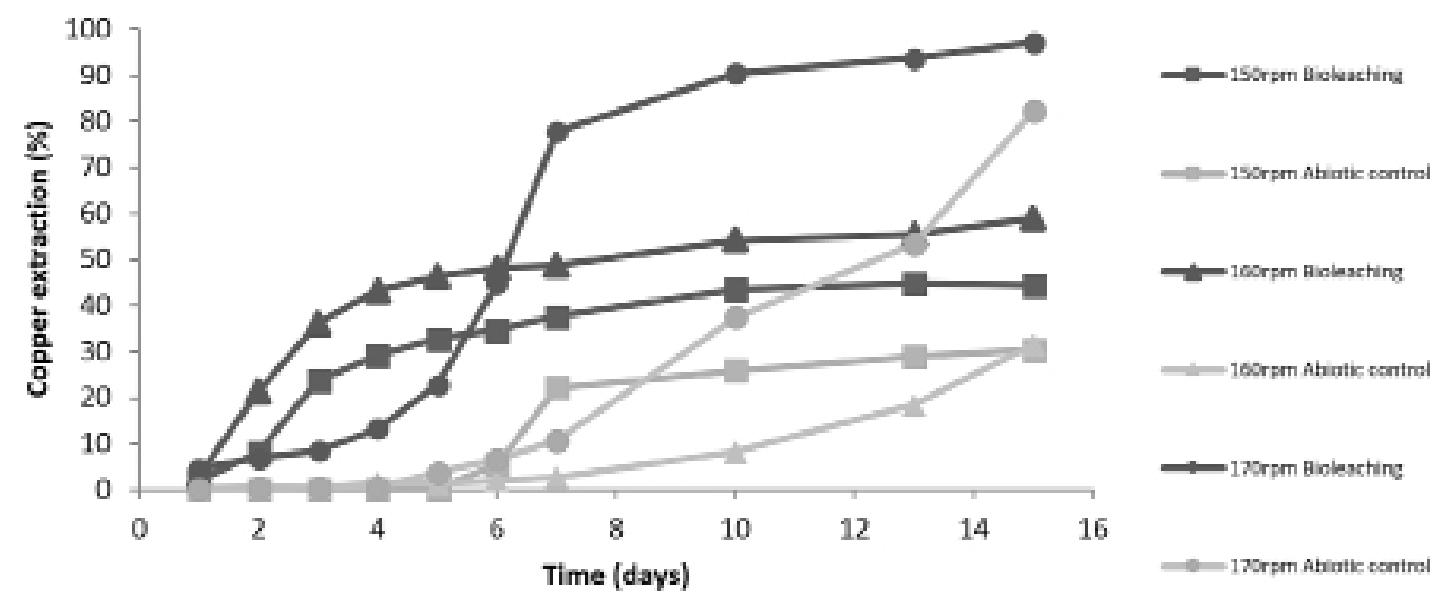

Figure 4. Copper extraction (\%) from I up to I5 days with speed rotation of: I50 rpm ( $\mathbf{\square}), I 60 \mathrm{rpm}(\boldsymbol{\Delta})$ and I $70 \mathrm{rpm}(\bullet)$, and the respective abiotic controls $150 \mathrm{rpm}(\square), 160 \mathrm{rpm}(\Delta)$ and $170 \mathrm{rpm}(\circ)$. 


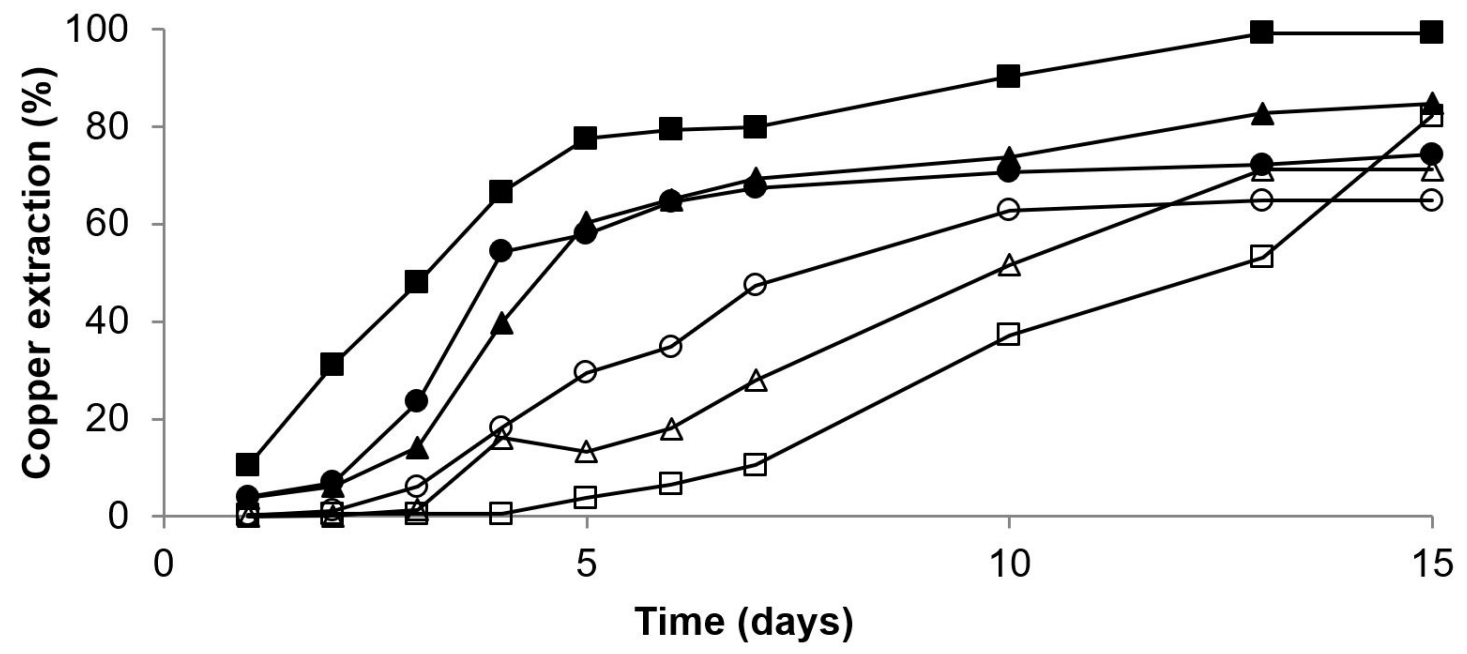

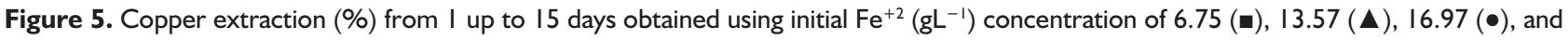
the respective abiotic controls $6.75(\square), 13.57(\Delta), 16.97(\circ)$.

in an experimental way, and as in the case of the bacterial adaptation process, factors such as the biomass used and the culture environment can cause the rotation speed to vary, and therefore it is necessary to investigate this.

In previous literature using A. ferrooxidans, Choi et al. [39] detected that the addition of ferrous ion to the bioleaching process promotes the dissolution of copper from PCBs.

The copper extraction is shown in Figure 5 for different $\mathrm{Fe}^{+2}$ initial concentrations. The experiment that assessed the influence of the increase in the initial concentration of $\mathrm{Fe}^{+2}$ on the bioleaching of printed circuit boards was carried out at the same time as the study of the influence of the volume of the oxidized culture solution (Figure 4). Since the percentage of copper extracted in both the studies was one of $99 \%$, the results presented using an initial concentration of $\mathrm{Fe}^{+2}$ of $6.75 \mathrm{gL}^{-1}$ and $10 \% \mathrm{v} / \mathrm{v}$ have already been discussed. However, this experiment helped prove the inhibiting effect that concentrations of $\mathrm{Fe}^{+2}\left(13.57\right.$ and $\left.16.97 \mathrm{gL}^{-1}\right)$ can have on the extraction of copper.

Figure 5 shows that the increase in the initial concentration of ferrous ion did not lead to an increase in copper extraction, as expected, given that biological activity is closely linked to oxidization of the ferrous ion. However, according to previous studies [24], concentrations of $\mathrm{Fe}^{+2}$ greater than $5 \mathrm{~kg} \mathrm{~m}^{-3}$ present an inhibiting effect on microbial growth. In both the situations studied, the extraction obtained was in excess of $70 \%$.

Aditionally, Choi et al. [39] demonstrated that the bioleaching of printed circuit boards with different initial concentrations of $\mathrm{Fe}^{+2}\left(0-9 \mathrm{gL}^{-1}\right)$ reached a higher solubilization of copper $\left(5 \mathrm{gL}^{-1}\right)$ using $7 \mathrm{gL}^{-1} \mathrm{de} \mathrm{Fe}^{+2}$, which is a similar level to the one obtained in this study $\left(6.75 \mathrm{gL}^{-1}\right)$.

Similar conclusions were observed by Xiang et al. [40] the copper is better bioleached by increasing the initial concentration of $\mathrm{Fe}^{+2}$ from 0 to $9 \mathrm{gL}^{-1}$, but it decrases in the concentrations of 12 and $15 \mathrm{gL}^{-1}$. Also in this study, the leaching rate of the copper decreased with the time of

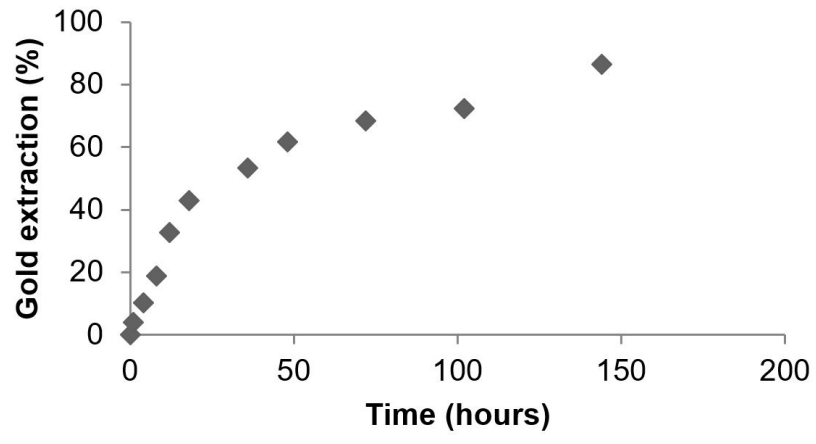

Figure 6. Cyanidation gold extraction (\%) by time (hours) of unbioleached material.

incubation, and it was suggested that this occurred due to the precipitation of $\mathrm{Fe}^{+3}$ and formation of a passivation layer on the surface of the ground $\mathrm{PCB}$, which explains the decrease in the extraction of copper at the initial concentrations of $\mathrm{Fe}^{+2}\left(12\right.$ and $\left.15 \mathrm{gL}^{-1}\right)$.

\subsection{Cyanidation}

The results from the alkaline leaching with sodium cyanide of bioleaching tailings show that $86 \%$ of the gold present in the insoluble material was extracted after 144 hours of leaching (Figure 6).

Gold extraction was prominent during the first 20 hours of cyanidation reaching almost $40 \%$ of the total gold extraction. The remaining gold was slowly extracted until it reached a level of $86 \%$ over the course of I 44 hours, given that gold may dissolve slowly in sodium cyanide [4I]. According to Ciminelli and Gomes [26], despite being thermodynamically favored, gold extraction in cyanidic solutions is limited by the slow reaction speed.

Brittain [42], who studied the kinetics of the dissolution of gold by cyanide, describes that as the cyanidation reaction 
continues and the concentration of gold in the solid fraction decreases, there is an increase in the resistance to the gold's dissolution. Zheng et al. [43] correlates this resistance to the formation of a passivation layer on the surface of the gold. The build-up of coatings, such as $\mathrm{AuCN}, \mathrm{AuOH}, \mathrm{Au}(\mathrm{OH})$ $(\mathrm{CN})^{-}, \mathrm{Au}(\mathrm{OH})(\mathrm{CN})^{3-}, \mathrm{Au}(\mathrm{OH})_{3}, \mathrm{Au}_{2} \mathrm{O}_{3}, \mathrm{AgCN} \cdot \mathrm{AuCN}$, $\mathrm{Au}_{2} \mathrm{~S}, \mathrm{Au}_{2} \mathrm{~S} \cdot \mathrm{S}$, delays the gold's cyanidation, as they act as passivators, blocking the reagents from the gold's surface [44].

\section{CONCLUSIONS}

The combined mechanical bio-hydrometallurgical processing of printed circuit boards succeded in the extraction of $99 \%$ of total copper content in 15 days of the bioleching process using $A$. ferroxidans-LR bacteria and $86 \%$ of the gold in I $44 \mathrm{~h}$ of cyanide leaching. Iron was recovered by magnetic separation (95\%). The best conditions for copper extraction were at a slurry density of $15 \mathrm{gL}^{-1}$, an inoculum (adapted bacteria) volume of $10 \%(\mathrm{v} / \mathrm{v})$, a rotation speed of $170 \mathrm{rpm}$, and an initial concentration of $\mathrm{Fe}^{+2}$ of $6.75 \mathrm{gL}^{-1}$.

The combination of the mechanical, microbiological and chemical processes made it possible to define an alternative route for selective and sequential extraction of the iron, copper and gold even considering with slow reaction speed due to the low cost, and it can be applied as a cheaper technical solution to PCB recycling in Brazil.

\section{Acknowledgements}

This project was supported by Fundação de Amparo à Pesquisa do Estado de São Paulo (FAPESP - process 08/53254-I and $10 / 51009-0)$.

\section{REFERENCES}

I Andrade DF, Romanelli JP, Pereira-Filho ER. Past and emerging topics related to electronic waste management: top countries, trends, and perspectives. Environmental Science and Pollution Research International. 2019;26:17135I7I5I.

2 Abdelbasir SM, Hassan SSM, Kamel AH, El-Nasr RS. Status of electronic waste recycling techniques: a review. Environmental Science and Pollution Research International. 2018;25:16533-16547.

3 Odeola FO. WEEE generation and the consequences of its improper disposal. In: Vegliò F, Birloaga I. Waste electrical and electronic equipment recycling - aqueous recovery methods. Cambridge: Woodhead Publishing Series in Electronic and Optical Materials; 2018. p. I3-3I.

4 Serafim M, Maia M. Tratamento do resíduo eletrônico na perspectiva da inclusão social. In: Costa AB. Tecnologia social \& políticas públicas. São Paulo: Instituto Pólis; Brasília: Fundação Banco do Brasil; 20 I3. p. 85-II 2.

5 Rodrigues AC. Fluxo domiciliar de geração e destinação de resíduos de equipamentos elétricos e eletrônicos no município de São Paulo/SP: caracterização e subsídios para políticas públicas [tese] São Paulo: Universidade de São Paulo; 2012.

6 Araújo MG. Modelo de avaliação do ciclo de vida para a gestão de resíduos de equipamentos eletroeletrônicos no Brasil [tese] Rio de Janeiro: Universidade Federal do Rio de Janeiro; 2013.

7 Agência Brasileira de Desenvolvimento Industrial, organizador. Logística reversa de equipamentos eletroeletrônicos: análise da viabilidade técnica e econômica. Brasília: ABDI; 20I3. 179 p.

8 Cui J, Zhang L. Metallurgical recovery of metals from electronic waste: a Review. Journal of Hazardous Materials. 2008; I58:228-256.

9 Park YJ, Fray DJ. Recovery of high purity precious metals from printed circuit boards. Journal of Hazardous Materials. 2009; I64:II52-II58.

10 Zeng X, Zheng L, Xie H, Lu B, Xia K, Chao K, et al. Current status and future perspective of waste printed circuit boards recycling. Procedia Environmental Sciences. 2012;16:590-597.

I I Chen Y, Sheu J-B, Lirn T-C. Fault tolerance modeling for an e-waste recycling supply chain. Transportation Research Part E, Logistics and Transportation Review. 2012;48:897-906.

12 Tsydenova O, Bengtsson M. Chemical hazards associated with treatment of waste electrical and electronic equipment. Waste Management (New York, N.Y.). 20 I I;3 I:45-58.

13 Pant D, Joshi D, Upreti M, Kotnala R. Chemical and biological extraction of metals present in E-waste: a hybrid technology. Waste Management (New York, N.Y.). 201 2;32:979-990.

14 Anjum F, Shahid M, Akcil A. Biohydrometallurgy techniques of low grade ores: a review on black shale. Hydrometallurgy. 2012;1I7-II8:I-I2. 
Yamane et al.

I5 Garcia O Jr. Estudos da Biolixiviação de Minérios de Urânio por Thiobacillus ferrooxidans [tese]. Campinas: Instituto de Biologia, Universidade Estadual de Campinas; 1989.

I6 Lynn NS. The bioleaching and processing of refractory gold ore: overview. Journal of the Minerals Metals \& Materials Society. 1997;49:24-26.

17 Das N. Recovery of precious metals through biosorption - A review. Hydrometallurgy. 20 10; 103:180- I89.

18 Fuente-Núñez C, Reffuveille F, Fernández L, Hancock R. Bacterial biofilm development as a multicellular adaptation: antibiotic resistance and new therapeutic strategies. Current Opinion in Microbiology. 20 I 3; 16:580-589.

19 Quatrini R, Johnson DB. Acidithiobacillus ferrooxidans. Trends in Microbiology. 2019;27:282-283.

$20 \mathrm{Gu}$ W, Bai J, Dong B, Zhuang X, Zhao J, Zhang C, et al. Catalytic effect of graphene in bioleaching copper from waste printed circuit boards by Acidithiobacillus ferrooxidans. Hydrometallurgy. 2017; I7I:172-178.

2I Priya A, Hait S. Extraction of metals from high grade waste printed circuit board by conventional and hybrid bioleaching using Acidithiobacillus ferrooxidans. Hydrometallurgy. 20 I8; 177:132-139.

22 Wang S, Chen L, Zhou X, Yan W, Ding R, Chen B, et al. Enhanced bioleaching efficiency of copper from printed circuit boards without iron loss. Hydrometallurgy. 20।8; I80:65-7I.

23 Tuovinen $\mathrm{OH}$, Kelly DP. Studies on the growth of Thiobacillus ferrooxidans - Use of membrane filters and ferrous iron agar to determine viable number and comparison $\mathrm{CO}_{2}$ fixation and iron oxidation as measures of growth. Archives of Microbiology. 1973;88:285-298.

24 Nemati M, Harrison STL, Hansford GS, Webb C. Biological oxidation of ferrous sulfate by Thiobacillus ferrooxidans: a

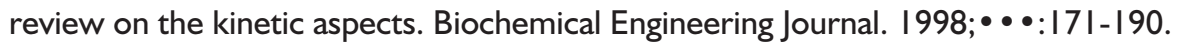

25 Yamane LH, Moraes VT, Espinosa DC, Tenório JA. Recycling of WEEE: Characterization of spent printed circuit boards from mobile phones and computers. Waste Management (New York, N.Y.). 20 I I;3 I:2553-2558.

26 Ciminelli VST, Gomes ADG. Princípios da cianetação. In: Trindade RBE, Barbosa O Fo. Extração do ouro princípios, tecnologia e meio ambiente. Rio de Janeiro: Centro de Tecnologia Mineral; 2002. p. 5I-82.

27 Mousav SM, Yaghmaei S, Salimi F, Jafari A. Influence of process variables on biooxidation of ferrous sulfate by an indigenous Acidithiobacillus ferrooxidans. Part I: flask experiments. Fuel. 2006;85:2555-2560.

28 Liang G, Tang J, Liu W, Zhou Q. Optimizing mixed culture of two acidophiles to improve copper recovery from printed circuit boards (PCBs). Journal of Hazardous Materials. 20I 3;250-25 I:234-245.

29 Guo Q, Yue X, Wang M, Liu Y. Pyrolisis of scrap printed circuit board plastic particles in a fluidized bed. Powder Technology. 2010; 198:422-428.

30 Ilyas S, Anwar MA, Nianzi SB, Ghauri MA. Bioleaching of Metals from Electronic Scrap by Moderately Thermophilic Acidophilic Bacteria. Hydrometallurgy. 2007;88: I80-I88.

3I Li H-M, Ke J-J. Influence of $\mathrm{Ni}^{+2}$ and $\mathrm{Mg}^{+2}$ on the growth and activity of $\mathrm{Cu}^{+2}$-adapted Thiobacillus ferrooxidans. Hydrometallurgy. 200I;6I:I5I-I56.

32 Yang Y, Diao M, Liu K, Qian L, Nguyen A, Qiu G. Column bioleaching of low-grade copper ore by Acidithiobacillus ferrooxidans in pure and mixed cultures with a heterotrophic acidophile Acidiphilium sp. Hydrometallurgy. 20 I 3; I I 132:93-98.

33 Brandl HB, Bosshard R, Wegmann M. Computer-munching microbes: metal leaching from electronic scrap by bacteria and fungi. Hydrometallurgy. 2001;59:319-326.

34 Wang J, Bai J, Xu J, Liang B. Bioleaching of metals from printed wire boards by Acidithiobacillus ferrooxidans and Acidithiobacillus thiooxidans and their mixture. Journal of Hazardous Materials. 2009; I 72: I I00-I I 05.

35 Vestola E, Kuusenaho MK, Narhi HM, Tuovinen OH, Puhakka JA, Plumb J], et al. Acid bioleaching of solid waste materials from copper, steel and recycling industries. Hydrometallurgy. 2010;103:74-79.

36 Gaylard C. Bioextraction and biodeterioration of metals. Cambridge: Cambridge University Press; I995. p. I54.

37 Valdívia DNU. Bacterial leaching of refractory gold ores [thesis] São Paulo: Universidade de São Paulo; 20 I 3.

38 Lewis G, Gaydardzhiev S, Bastin D, Barrel P. Bio hydrometallurgical Recovery of Metals from Fine Shredder Residues. Minerals Engineering. 201 I;24: I I66-II7I.

39 Choi M-S, Cho K-S, Kim D-S, Kim D-J. Microbial recovery of copper from printed circuit boards of waste computer by Acidithiobacillus ferrooxidans. Journal of Environmental Science and Health. 2004;A39: I- 10.

40 Xiang Y, Wu P, Zhu N, Zhang T, Liu W, Wu J, et al. Bioleaching of copper from waste printed circuit boards by bacterial consortium enriched from acid mine drainage. Journal of Hazardous Materials. 2010;184:81 2-8I8. 
4I Mendhan J, Denney RC, Barnes JD, Thomas MJK. Vogel's quantitative chemical analysis. 6th ed. England: Prentice Hall; 2000.

42 Brittain MI. Variables activation energy model for leaching kinetics. Rio de Janeiro: Centro de Tecnologia Mineral; 2002. p. 32I-33I.

43 Zheng J, Ritchie IM, La Brooy SR, Singh P. Study of gold leaching in oxygenated solutions containing cyanide-copperammonia using rotating quartz crystal microbalance. Hydrometallurgy. 1995;99:277-292.

44 Senanayake G. A review of effects of silver, lead, sulfide and carbonaceous matter on gold cyanidation and mechanistic interpretation. Hydrometallurgy. 2008;90:46-73.

Received: 13 Feb. 2019

Accepted: 9 Mar. 2020 